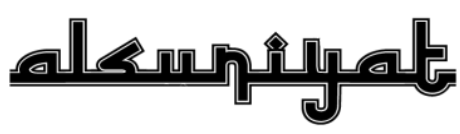

JURNAL PENELITIAN BAHASA, SASTRA, DAN

BUDAYA ARAB

P-ISSN: 2615-7241 | E-ISSN: 2721-480X // Vol. 2 No. 1 | 72-83

(1) https://ejournal.upi.edu/index.php/alsuniyat/index

\title{
Madlipz dalam Pembelajaran Daring Mahārah Istimā': Implementasi dan Analisis Persepsi Siswa
}

\author{
Noor Amalina Audina ${ }^{1}$, Mahfuz Rizqi Mubarak ${ }^{2}$ \\ ${ }^{1}$ Universitas Islam Negeri Maulana Malik Ibrahim Malang, Indonesia \\ ${ }^{2}$ Institut Agama Islam Negeri Palangka Raya, Indonesia \\ E-mail: nooramalinaaudina@yahoo.com
}

\begin{abstract}
:
This researcher aims to explore the listening skill' online learning process using the Madlipz application and analyze the students' perceptions of the learning process. This study used a descriptive qualitative approach with three data collection techniques, namely observation, interviews, and documentation. From this study, the researchers concluded three steps used by the teacher, namely (1) preparing and sharing online class links using Zoom Cloud Meeting media, (2) several core activities such as greeting, motivation, and explanation of listening skill 'learning objectives'. In this step, it is also explained how the videos provided by the Madlipz application are presented as teaching materials for listening skill 'learning, (3) evaluating learning outcomes. Researchers also found various kinds of students' perceptions which were categorized as positive and negative perceptions.

Keywords:

Listening Skill; Madlipz; Student's Perception
\end{abstract}

\begin{abstract}
Abstrak
Peneliti ini bertujuan untuk mengeksplorasi proses pembelajaran daring mahārah istimä'dengan menggunakan aplikasi Madlipz, serta analisis persepsi para siswa dari proses pembelajaran tersebut. Penelitian ini menggunakan pendekatan kualitatif deskriptif dengan tiga teknik pengumpulan data yakni observasi, wawancara, dan dokumentasi. Dari penelitian ini, peneliti menyimpulkan tiga langkah yang digunakan pengajar yakni, (1) menyiapkan dan membagikan link kelas daring menggunakan media Zoom Cloud Meeting, (2) beberapa kegiatan inti seperti ucapan salam, motivasi, dan penjelasan tujuan pembelajaran mahārah istimä'. Pada langkah ini juga dijelaskan bagaimana video-video yang disediakan aplikasi Madlipz disajikan sebagai bahan ajar dari pembelajaran istimä', (3) evaluasi hasil pembelajaran. Peneliti juga menemukan berbagai macam persepsi siswa yang dikategorisasikan dengan persepsi positif dan negatif.

Kata Kunci:

Madlipz; Mahārah Istimā'; Persepsi Siswa
\end{abstract}

\section{PENDAHULUAN}

Pandemi COVID-19 yang terjadi sejak awal tahun 2020 telah mengubah wajah pendidikan di seluruh dunia (Supiani dkk., 2020). Virus yang pertama kali teridentifikasi di Wuhan, Cina kini telah menyebar ke berbagai belahan dunia (Taloko dkk., 2020). Hal ini berdampak kepada perubahan kebijakan model pembelajaran dari tatap muka menjadi sistem daring (Corbera dkk., 2020; Morgan, 2020; Murphy, 2020; Susanto dkk., 2020).

Implementasi pembelajaran secara daring atau yang dikenal dengan pembelajaran dalam jaringan menekankan teknologi informasi dan jaringan internet dalam penggunaannya (Choudhury \& Pattnaik, 2020). Hal ini tentunya menuntut para pendidik untuk beradaptasi dalam mengembangkan inovasi pembelajaran (Moorhouse, 2020; Xue dkk., 2020; Zhu \& Liu, 2020), mengingat tidak semua pendidik berpengalaman dalam pembelajaran daring. Maka dari 
ALSUNIYAT: Jurnal Penelitian Bahasa, Sastra, dan Budaya Arab

itu, penguasan teknologi untuk para pendidik menjadi hal yang sangat urgen sebagai bekal dalam pelaksanaan pembelajaran secara daring (Corbera dkk., 2020).

Berbagai pilihan platform ditawarkan oleh beberapa peneliti untuk digunakan dalam pembelajaran daring. Mubarak dkk. dalam laporannya mengungkapkan bahwa Zoom Cloud Meeting mampu menggantikan model pembelajaran tatap muka secara virtual tanpa harus berkumpul di dalam satu ruangan yang berpotensi pada penularan Covid-19 (Mubarak, Wahdah, dkk., 2020b). Begitu juga Al-Maroof dkk. dalam hasil penelitiannya merekomendasikan Google Meet (GM) sebagai solusi potensial dalam menghadapi situasi pandemi yang terjadi saat ini. GM memberikan keamanan kepada para pengguna baik pendidik maupun peserta didik dalam pelaksanaan pembelajaran secara tatap muka menggunakan smartphone atau laptop (Al-Maroof dkk., 2020). Terakhir, Simamora dalam hasil penelitiannya melaporkan bahwa media sosial WhatsApp memungkinkan pendidik dan peserta didik saling berbagi bahan yang digunakan dalam proses pembelajaran secara daring (Simamora, 2020).

Selain itu, upaya untuk meningkatkan motivasi belajar peserta didik di masa pandemi Covid-19 menjadi suatu hal yang penting. Ferdiansyah dkk. melaporkan bahwa pandemi Covid19 membuat motivasi belajar menjadi tidak stabil (Ferdiansyah dkk., 2020). Bahkan Hastowohadi dkk. menegaskan bahwa pelaksanaan pembelajaran secara daring memengaruhi kondisi emosional seperti munculnya perasaan sedih, kecewa, cemas, dan pasrah (Hastowohadi dkk., 2020). Maka dari itu, perlu adanya solusi untuk menangani kondisi emosional tersebut.

Penggunaan media pembelajaran menjadi salah satu solusi untuk meningkatkan motivasi peserta didik, serta membantu dalam memahami materi yang diajarkan ketika mengikuti proses pembelajaran (Barra dkk., 2014; Herbst \& Chazan, 2015; Kumar dkk., 2019). Maka dari itu, para pendidik dituntut untuk mengaplikasikan media pembelajaran berbasis teknologi, guna mengatasi demotivasi peserta didik dan membantu dalam pencapaian tujuan pembelajaran.

Salah satu pengajar di lembaga pembelajaran bahasa Arab Al-Azhar yang terletak di Provinsi Jawa Timur menggunakan aplikasi Madlipz dalam pelaksanaan pembelajaran daring mahārah istimā' (listening skill). Aplikasi Madlipz adalah salah satu media yang populer di kalangan remaja masa kini. Rilis sejak tahun 2017 dan tersedia untuk umum mulai bulan April tahun 2018, aplikasi ini telah diakses sebanyak 10 juta pengguna (Amazon.com: Madlipz - Make A Voice Over Parody!: Appstore for Android, tt.), dan dapat diunduh secara gratis di Google Play 
ALSUNIYAT: Jurnal Penelitian Bahasa, Sastra, dan Budaya Arab

Store maupun App Store. Madlipz memungkinkan para pengguna menjadi pengisi suara (dubber) yang disesuaikan dengan potongan video atau film yang disajikan (Rachman dkk., 2020). Jika dibandingkan dengan beberapa aplikasi dubbing lainnya seperti Follywood dan Dubme, aplikasi Madlipz memiliki beberapa fitur unggulan seperti video atau film kartun yang dapat digunakan secara gratis dan mudah dalam penggunaannya.

Sedangkan mahārah istimā' adalah keterampilan berbahasa pertama yang terlebih dahulu harus dikuasi oleh para pembelajar mengingat secara alamiah pertama kali manusia memahami bahasa orang lain melalui mendengar (Hamidah \& Marsiah, 2020). Keterampilan menyimak (mahārah istimā') mengarah kepada kemampuan seseorang dalam mencerna dan memahami kata atau kalimat yang yang diujarkan oleh mitra bicara (Nuha, 2016).

Namun, penelitian mengenai Madlipz sebagai media pembelajaran mahārah istimā' masih sangat sedikit. Dari hasil penelusuran peneliti melalui Google Scholar, peneliti hanya menemukan satu penelitian yang telah dilakukan oleh Rachman, dkk (2020). Mereka menyimpulkan bahwa aplikasi Madlipz mendapat respon positif dari kalangan mahasiswa EFL (English Foreign Language). Mereka beranggapan bahwa aplikasi Madlipz memberikan pengalaman belajar listening yang menarik, menghibur, dan juga menantang. Madlipz berkontribusi dalam melatih kemampuan pendengaran mereka melalui fitur video yang disajikan serta mempraktikkan apa yang telah didengar secara lisan (Rachman dkk., 2020).

Maka dari itu, peneliti tertarik untuk mengeksplorasi lebih dalam tentang bagaimana implementasi aplikasi Madlipz dalam pembelajaran daring mahārah istimā', dan bagaimana persepsi peserta didik dalam menyikapi implementasi aplikasi Madlipz pada pembelajaran tersebut. Temuan dalam penelitian ini diharapkan dapat memberikan wawasan baru mengenai aplikasi Madlipz yang diimplementasikan dalam pembelajaran bahasa Arab khususnya yang diselenggarakan secara daring.

\section{METODE}

Penelitian ini menggunakan pendekatan kualitatif deskriptif yang menghasilkan data deskriptif berupa kata-kata tertulis atau lisan dari orang-orang dan perilaku yang diamati (Taylor dkk., 2015). Penelitian ini bermaksud untuk mengeksplorasi implementasi aplikasi Madlipz dalam pembelajaran daring mahārah istimā' yang diselenggarakan oleh lembaga AlAzhar yang terletak di Provinsi Jawa Timur. Peneliti juga mengeksplorasi persepsi siswa mengenai proses pembelajaran mahārah istimā' dengan menggunakan aplikasi Madlipz. 
ALSUNIYAT: Jurnal Penelitian Bahasa, Sastra, dan Budaya Arab

Meskipun diselenggarakan secara daring, lembaga Al-Azhar tersebut tetap menerapkan sistem pemisahan antara kelas laki-laki dan perempuan. Dalam penelitian ini, peneliti hanya mengeksplorasi proses pembelajaran daring mahārah istimā' yang diselenggarakan untuk kelas wanita. Lima orang partisipan dengan nama inisial NAD (24 Tahun), LH (20 tahun), AMS (18 tahun), AS (19 tahun), dan SH (19 tahun) bersedia menjadi partisipan dalam penelitian ini (Lihat Tabel 1).

Tabel 1.

Data Demografi Partisipan

\begin{tabular}{cccccc}
\hline No & $\begin{array}{c}\text { Nama } \\
\text { (Inisial) }\end{array}$ & $\begin{array}{c}\text { Jenis } \\
\text { Kelamin }\end{array}$ & Umur & Status & $\begin{array}{c}\text { Pendidikan } \\
\text { Terakhir }\end{array}$ \\
\hline 1 & NAD & Wanita & 24 & Pengajar & Sarjana \\
2 & LH & Wanita & 20 & Siswa & $\begin{array}{c}\text { Pondok } \\
\text { Pesantren }\end{array}$ \\
3 & AMS & Wanita & 18 & Siswa & MA \\
4 & AS & Wanita & 19 & Siswa & MA \\
5 & SH & Wanita & 19 & Siswa & MA \\
\hline
\end{tabular}

Perekrutan partisipan dilakukan dengan tiga alasan utama yakni: (1) kesediaan mereka untuk memberikan informasi secara utuh yang berkaitan dengan proses pembelajaran daring mahārah istimā' dengan menggunakan aplikasi Madlipz, (2) adanya kedekatan emosional seperti pertemanan yang akrab antara peneliti dengan pengajar, (3) kedekatan emosional pengajar dengan keempat siswa yang juga menjadi partisipan dalam penelitian ini. Beberapa alasan tersebut memudahkan para peneliti untuk mengeksplorasi proses pembelajaran secara mendalam.

Dalam penelitian ini, peneliti menggunakan tiga teknik pengumpulan data yakni, observasi, wawancara, dan dokumentasi. Observasi berfungsi untuk mengamati proses pembelajaran daring mahārah istimā' menggunakan aplikasi Madlipz yang diimplementasikan oleh pengajar. Wawancara berfungsi untuk mengkonfirmasi proses implementasi penggunaan aplikasi Madlipz kepada pengajar yang bersangkutan, serta menggali data mengenai persepsi siswa di lembaga informal tentang implementasi dari penggunaan aplikasi tersebut. Dokumentasi dari penelitian ini berupa foto hasil pembelajaran mahārah istimā' dengan menggunakan aplikasi Madlipz. 
ALSUNIYAT: Jurnal Penelitian Bahasa, Sastra, dan Budaya Arab

\section{HASIL DAN PEMBAHASAN}

Dalam penelitian ini, peneliti merumuskan dua hasil penelitian yakni: (1) implementasi aplikasi Madlipz dalam pembelajaran mahārah istimā', dan (2) persepsi peserta didik tentang implementasi aplikasi Madlipz dalam pembelajaran mahārah istimā'.

\section{Implementasi Aplikasi Madlipz dalam Pembelajaran Daring Mahārah Istimā'}

Dari hasil wawancara terhadap pengajar berinisial NAD, Penggunaan aplikasi Madlipz dalam pembelajaran mahārah istimā' didasarkan oleh beberapa alasan, yakni: Pertama, NAD menuturkan bahwa pandemi yang terjadi saat ini berimbas pada kesenjangan interaksi sosial antara dia sebagai pengajar dan para siswa khususnya pada proses pembelajaran istimā'. Hal ini menuntut penggunaan media yang berfungsi untuk melancarkan proses pembelajaran dan setidaknya dapat meminimalisir terjadinya kesenjangan tersebut.

Kedua, dari hasil wawancara, NAD mengungkapkan bahwa aplikasi Madlipz adalah aplikasi yang sangat sederhana dalam penggunaannya dan dapat diaplikasikan di semua gadget baik yang beroperasi menggunakan sistem Android maupun IOS.

Ketiga, NAD menuturkan bahwa aplikasi Madlipz memiliki karakteristik yang mendukung para pengajar untuk menyiapkan materi pembelajaran mahārah istimā'. Madlipz menyediakan fitur berupa rekaman dubbing suara oleh pengajar yang menyesuaikan dengan ekspresi dari potongan-potongan video yang tersedia oleh aplikasi tersebut. Hasil rekaman materi yang disiapkan oleh pengajar video Madlipz, dapat digunakan sebagai bahan ajar mahārah istimā'.

Dari hasil wawancara di atas, peneliti menemukan bahwa pengajar lembaga informal tersebut memiliki tiga alasan mendasar dalam penggunaan aplikasi Madlipz sebagai media pembelajaran mahārah istimā', yakni: (1) hilangnya interaksi antar muka (face to face) yang disebabkan oleh pandemi covid-19. Hal ini senada dengan hasil penelitian Murphy yang melaporkan bahwa perubahan sistem pembelajaran dari luring (luar jaringan) menjadi daring (dalam jaringan) yang diakibatkan oleh pandemi, berpengaruh terhadap kesenjangan interaksi antara pengajar dengan siswa (Murphy, 2020). (2) Kemudahan dalam penggunaan aplikasi Madlipz untuk menunjangan proses pembelajaran. Hal ini senada dengan hasil penelitian Haniah yang melaporkan bahwa kemajuan teknologi memberikan dampak positif bagi kemajuan dunia pendidikan (Haniah, 2014). Ilmiani dkk. dalam penelitiannya juga melaporkan bahwa, berbagai macam media interaktif dari hasil kemajuan teknologi ditawarkan untuk meminimalisir berbagai macam problematika yang terjadi khususnya pada proses 
ALSUNIYAT: Jurnal Penelitian Bahasa, Sastra, dan Budaya Arab

pembelajaran bahasa Arab (Ilmiani dkk., 2020). (3) Kesesuaian karakteristik antara mahārah istimā' dengan aplikasi Madlipz. Hal ini senada dengan hasil penelitian Mubarak dkk. yang melaporkan bahwa kesamaan karakteristik antara materi dan media yang akan digunakan dalam proses pembelajaran, memberikan keuntungan terhadap pengajar maupun siswa (Mubarak, Wahdah, dkk., 2020).

Peneliti juga melakukan observasi untuk memperoleh data tentang langkah-langkah implementasi aplikasi Madlipz dalam pelaksanaan pembelajaran mahārah istimā'. Dari observasi, peneliti menemukan beberapa langkah sebagaimana berikut:

Pertama, pengajar menyiapkan link pertemuan secara daring dengan menggunakan media Zoom Cloud Meeting dan membagikannya melalui media WhatsApp group kelas. Pengajar mempersilahkan para siswa untuk masuk kelas virtual melalui link yang telah dibagikan tersebut. Setelah seluruh siswa bergabung ke dalam kelas virtual, pengajar memulai proses pembelajaran mahārah istimā'.

Kedua, dalam kegiatan inti, pengajar memulai pembelajaran dengan mengucapkan salam, memberikan motivasi serta menyampaikan tujuan dari pembelajaran mahārah istima ${ }^{\prime}$ yang akan diselenggarakan pada hari tersebut. Data ini juga diperkuat oleh hasil wawancara peneliti bersama NAD yang mengungkapkan bahwa, pemberian motivasi di awal pembelajaran daring sangat penting dilakukan mengingat pandemi covid-19 yang terjadi saat ini berpengaruh terhadap demotivasi belajar para siswa dikarenakan kurangnya interaksi antara pengajar dan siswa. Dalam implementasi aplikasi Madlipz, pengajar menggunakan fitur share screen dari media Zoom Cloud Meeting untuk menampilkan bahan ajar pembelajaran mahārah istimä' yang disajikan menggunakan potongan-potongan video Madlipz. Sebelumnya, pengajar telah menyediakan tiga bahan ajar berbentuk potongan video Madlipz dengan tema الأعمال اليومية (kegiatan sehari-hari) yang akan digunakan dalam pembelajaran mahārah istimā'. Dari hasil wawancara, NAD menguatkan bahwa potongan video yang disajikan oleh Madlipz hanya berdurasi selama 30 detik. Maka dari itu, pengajar tersebut berinisiatif untuk menyediakan tiga potongan video langsung dalam satu pertemuan. Satu video ditampilkan melalui fitur share screen sebanyak tiga kali, dan siswa diminta untuk mendengarkan secara seksama dari kalimat yang diperdengarkan melalui video Madlipz.

Ketiga, pada tahap evaluasi, pengajar menanyakan satu per satu kepada para siswa tentang hasil yang telah mereka dengarkan dari video Madlipz. Pengajar meminta para siswa untuk menjawab pertanyaan tersebut secara lisan. Dari hasil wawancara, NAD menambahkan 
ALSUNIYAT: Jurnal Penelitian Bahasa, Sastra, dan Budaya Arab

bahwa sebenarnya pengajar juga ingin meminta kepada para siswa untuk menjawab pertanyaan secara tertulis dengan memanfaatkan fitur chat yang tersedia di media Zoom Cloud Meeting. Namun, pengajar yang bersangkutan mengurungkan niat tersebut dengan pertimbangan bahwa tidak semua siswa menguasai penggunaan Arabic keyboard yang berpotensi menyulitkan para siswa dalam menjawab pertanyaan.

Dari hasil observasi yang juga dikuatkan oleh hasil wawancara, peneliti menyimpulkan bahwa implementasi aplikasi Madlipz yang digunakan oleh pengajar dalam pembelajaran mahārah istimā' menggunakan beberapa langkah, yakni: (1) Pengajar menyiapkan kelas virtual yang difasilitasi dengan menggunakan media Zoom Cloud Meeting. Hal ini menegaskan hasil penelitian Mubarak dkk. yang melaporkan bahwa media Zoom Cloud Meeting dapat dijadikan sebagai media alternatif dalam proses pembelajaran bahasa Arab di tengah wabah covid-19 (Mubarak, Wahdah, dkk., 2020b).

(2) Pengajar memberikan motivasi dan juga menyampaikan tujuan pembelajaran di awal kegiatan pembelajaran mahārah istimā'. NAD dalam hasil wawancara mengungkapkan bahwa pemberian motivasi belajar memiliki peran yang penting. Pandemi covid-19 berpengaruh terhadap demotivasi belajar siswa. Hal ini senada dengan hasil penelitian Raaper dan Brown yang melaporkan bahwa pandemi covid-19 berimplikasi pada demotivasi belajar siswa dan harus menjadi perhatian para pengajar dalam mengatasi problematika tersebut (Raaper \& Brown, 2020). Sebagaimana yang telah disebutkan di atas, bahwa faktor terjadinya demotivasi tidak lepas dari akibat kesenjangan relasi antara pengajar dan siswa yang terjadi di masa pandemi (Murphy, 2020). Motivasi belajar sangat berpengaruh terhadap keberhasilan siswa dalam mencapai tujuan dari pembelajaran tersebut (Liu dkk., 2015; Mubarak, Ahmadi, dkk., 2020; Nurtresnaningsih, 2018).

(3) Evaluasi pembelajaran mahārah istimā'. Evaluasi sejatinya dapat dilaksanakan secara lisan maupun tertulis. Namun, pengajar lebih merekomendasikan dengan melakukan evaluasi hasil apa yang telah siswa dengar secara lisan daripada secara tertulis untuk menghindari terjadinya kesulitan dalam menulis bahasa Arab dengan menggunakan fitur chat yang ada di media Zoom Cloud Meeting. Dari fenomena tersebut, peneliti menyimpulkan bahwa pengajar tidak memaksakan untuk melaksanakan evaluasi secara tertulis demi menghindari terjadinya kesulitan yang akan dihadapi oleh para siswa. Hal ini menegaskan hasil penelitian Fathoni yang melaporkan bahwa proses evaluasi pembelajaran bertujuan untuk mengukur hasil apa yang telah dipelajari siswa (Fathoni, 2018). Evaluasi berperang penting dalam 
ALSUNIYAT: Jurnal Penelitian Bahasa, Sastra, dan Budaya Arab

mengetahui ketercapaian dari tujuan pembelajaran (Kholisoh, 2018). Yang terpenting dari proses evaluasi adalah seberapa jauh tujuan dari pembelajaran tersebut tercapai (Fathoni, 2018).

\section{Persepsi Siswa tentang Implementasi Aplikasi Madlipz dalam Pembelajaran Mahārah Istimā'}

Pada bagian ini, peneliti menemukan beberapa persepsi dari para siswa yang mereka ungkapkan pada saat wawancara. Beberapa persepsi tersebut, peneliti kelompokkan dalam dua kategori yaitu persepsi positif dan persepsi negatif.

\section{Persepsi Positif}

Dari hasil wawancara, siswa LH mengungkapkan bahwa penggunaan aplikasi Madlipz memberikan pengalaman baru baginya dalam pembelajaran bahasa Arab. Siswa LH yang sebelumnya menempuh pendidikan di pondok pesantren yang melarang penggunaan alat teknologi seperti gadget, mendapatkan pengalaman baru dari penggunaan aplikasi Madlipz tersebut.

Adapun siswa AMS, siswa AS, dan siswa SH memiliki kesamaan persepsi dalam menyikapi implementasi aplikasi Madlipz dalam pembelajaran mahārah istimā'. Mereka mengungkapkan bahwa aplikasi Madlipz menyajikan video-video unik yang diambil dari potongan film cartoon. Meskipun terkadang beberapa ekspresi yang ditampilkan di video tidak sinkron dengan intonasi yang diucapkan dalam materi istimā', namun hal ini tidak terlalu berpengaruh terhadap proses pembelajaran. Mereka tetap fokus untuk mendengarkan kalimat apa yang diperdengarkan melalui video Madlipz tersebut.

\section{Persepsi Negatif}

Setiap hasil perkembangan teknologi, tentunya juga tidak lepas dari persepsi negatif. Dari hasil wawancara, siswa LH mengungkapkan bahwa aplikasi Madlipz lebih didominasi oleh video cartoon dengan karakter hewan. Di sisi lain, LH juga mengungkapkan bahwa video-video yang disajikan di aplikasi Madlipz juga memuat gambar-gambar manusia yang tidak menutup aurat (kurang islami).

Adapun siswa AMS mengungkapkan bahwa video-video yang disajikan di aplikasi Madlipz memiliki durasi yang sangat pendek yaitu hanya sebatas 30 detik. Meskipun pengajar memadukan dua video sekaligus dalam implementasinya, siswa AMS cenderung tidak setuju dengan perpaduan tersebut disebabkan oleh dua video yang dipadukan memiliki karakter atau 
ALSUNIYAT: Jurnal Penelitian Bahasa, Sastra, dan Budaya Arab

cerita yang berbeda. AMS juga menambahkan bahwa kualitas video yang dihasilkan dari aplikasi Madlipz memiliki resolusi yang rendah sehingga tidak terlalu nyaman untuk dilihat.

Terakhir, siswa AS dan SH lebih cenderung mengalami problematika pada aspek lemahnya sinyal internet. Mereka mengungkapkan bahwa lemahnya jaringan internet berimbas pada penyajian video Madlipz yang kurang sempurna. Video Madlipz yang disajikan pengajar melalui fitur share screen pada media Zoom Cloud Meeting akan mengalami kendala seperti video yang tersendat atau suara kurang jelas jika jaringan internet lemah.

Dari kedua persepsi di atas (positif maupun negatif) mengenai penggunaan aplikasi Madlipz, dapat disimpulkan bahwasanya kemajuan teknologi memberikan pengaruh yang signifikan dalam perkembangan media pembelajaran yang efektif dan efisien. Berbagai macam media telah diintegrasikan ke dalam model pembelajaran melalui teknologi (Armawi, 2018), guna mengatasi berbagai macam problematika yang terjadi dalam proses pembelajaran (Haniah, 2014; Ilmiani dkk., 2020).

Beberapa persepsi positif telah diungkapkan oleh para partisipan dalam penelitian ini seperti pengalaman baru, dan penyajian bahan ajar yang dikemas secara menarik menggunakan aplikasi Madlipz. Hal ini selaras dengan hasil penelitian Rachman dkk. yang melaporkan bahwa aplikasi Madlipz memberikan sajian video materi yang menarik sehingga para siswa tidak mengalami kejenuhan pada saat proses pembelajaran berlangsung (Rachman dkk., 2020). Namun, lemahnya jaringan internet masih menjadi kendala umum yang terjadi dalam proses pembelajaran daring. Apapun media yang digunakan dalam pembelajaran daring tidak pernah lepas dari kendala tersebut. Hal ini juga dilaporkan oleh beberapa peneliti seperti Albantani yang mengungkapan bahwa salah satu problematika dari pelaksanaan pembelajaran menggunakan Google Classroom adalah lemahnya jaringan internet (Rozak \& Albantani, 2018). Begitu juga Sa'diyah yang mengungkapkan bahwa lemahnya jaringan internet menjadi salah satu kendala dari implementasi WhatsApp group dalam pembelajaran mahārah kalām (Sa`diyah, 2019).

\section{SIMPULAN}

Hasil dari penelitian ini menunjukkan bahwa ada beberapa langkah yang diimplementasikan oleh pengajar dalam pelaksanaan pembelajaran daring mahārah istimā' menggunakan aplikasi Madlipz yakni: (1) Membagikan link kelas daring dengan media Zoom Cloud Meeting, (2) kegiatan inti berupa ucapan salam, pemberian motivasi, dan penjelasan tujuan dari pembelajaran mahārah istimā'. Pengajar menggunakan fitur share screen untuk 
ALSUNIYAT: Jurnal Penelitian Bahasa, Sastra, dan Budaya Arab

menyajikan bahan ajar mahārah istimā' yang disajikan menggunakan aplikasi Madlipz,

pengajar mengevaluasi hasil dari pembelajaran daring tersebut. Implementasi aplikasi Madlipz mendapat respon positif dari para siswa seperti mendapatkan pengalaman baru, dan sajikan video-video cartoon menarik yang disediakan oleh aplikasi Madlipz. Namun, beberapa mahasiswa juga memberikan respon negatif yang diakibatkan oleh lemahnya sinyal internet yang berdampak pada kualitas hasil sajian video pada saat pembelajaran berlangsung.

\section{DAFTAR PUSTAKA}

Al-Maroof, R. S., Salloum, S. A., Hassanien, A. E., \& Shaalan, K. (2020). Fear from COVID-19 and technology adoption: The impact of Google Meet during Coronavirus pandemic. Interactive Learning Environments, $\quad 0(0), \quad 16$. https://doi.org/10.1080/10494820.2020.1830121

Amazon.com. Madlipz-Make A Voice Over Parody!: Appstore for Android. (tt.). Retrieved December 13, 2020, from https://www.amazon.com/Madlipz-Make-Voice-OverParody/dp/B06Y24FTRB

Armawi, S. A. S. (2018). Pendayagunaan multimedia dalam pengajaran bahasa Arab. Jurnal Al Mabhats, 3(1), 01-23.

Barra, E., Herrera, S. A., Caño, J. Y. P., \& Vives, J. Q. (2014). Using multimedia and peer assessment to promote collaborative e-learning. New Review of Hypermedia and Multimedia, 20(2), 103-121. https://doi.org/10.1080/13614568.2013.857728

Choudhury, S., \& Pattnaik, S. (2020). Emerging themes in e-learning: A review from the stakeholders' perspective. Computers \& Education, 144, 103657. https://doi.org/10.1016/j.compedu.2019.103657

Corbera, E., Anguelovski, I., Honey-Rosés, J., \& Ruiz-Mallén, I. (2020). Academia in the time of COVID-19: Towards an Ethics of Care. Planning Theory \& Practice, 21(2), 191-199. https://doi.org/10.1080/14649357.2020.1757891

Fathoni, M. (2018). Pembelajaran mahārah istima'. Journal Ihtimam, 1(1), Article 1. https://journal.staimsyk.ac.id/index.php/ihtimam/article/view/162

Ferdiansyah, S., Supiastutik, \& Angin, R. (2020). Thai students' experiences of online learning at Indonesian Universities in the time of the COVID-19 pandemic. Journal of International Students, 10(S3), 58-74. https://doi.org/10.32674/jis.v10iS3.3199

Hamidah, H., \& Marsiah, M. (2020). Pembelajaran mahārah al-istima' dengan memanfaatkan media youtube: Problematika dan solusi. Al-Ta'rib: Jurnal Ilmiah Program Studi Pendidikan Bahasa Arab IAIN Palangka Raya, 8(2), 147-160. https://doi.org/10.23971/altarib.v8i2.2282

Haniah, H. (2014). Pemanfaatan teknologi informasi dalam mengatasi masalah belajar bahasa Arab. Al-Ta'rib: Jurnal Ilmiah Program Studi Pendidikan Bahasa Arab IAIN Palangka Raya, 2(1). https://doi.org/10.23971/altarib.v2i1.588 
Hastowohadi, Setyaningrum, R. W., \& Pangesti, F. (2020). Forced remote learning during the COVID-19 Outbreak. Journal of International Students, 10(S3), 180-197. https://doi.org/10.32674/jis.v10iS3.3206

Herbst, P., \& Chazan, D. (2015). Studying professional knowledge use in practice using multimedia scenarios delivered online. International Journal of Research \& Method in Education, 38(3), 272-287. https://doi.org/10.1080/1743727X.2015.1025742

Ilmiani, A. M., Ahmadi, A., Rahman, N. F., \& Rahmah, Y. (2020). Multimedia interaktif untuk mengatasi problematika pembelajaran bahasa Arab. Al-Ta'rib : Jurnal Ilmiah Program Studi Pendidikan Bahasa Arab IAIN Palangka Raya, 8(1), 17-32. https://doi.org/10.23971/altarib.v8i1.1902

Kholisoh, L. N. (2018). Sudahkah evaluasi kemahiran berbicara bahasa Arab pada tingkat dasar dilakukan?. ALSUNIYAT: Jurnal Penelitian Bahasa, Sastra, dan Budaya Arab, 1(1), 73-87. https://doi.org/10.17509/alsuniyat.v1i1.24200

Kumar, J. A., Muniandy, B., \& Yahaya, W. A. J. W. (2019). Exploring the effects of emotional design and emotional intelligence in multimedia-based learning: An engineering educational perspective. New Review of Hypermedia and Multimedia, 25(1-2), 57-86. https://doi.org/10.1080/13614568.2019.1596169

Liu, W. C., Wang, J. C. K., \& Ryan, R. M. (2015). Building autonomous learners: perspectives from research and practice using self-determination theory. Springer.

Moorhouse, B. L. (2020). Adaptations to a face-to-face initial teacher education course 'forced' online due to the COVID-19 pandemic. Journal of Education for Teaching, 0(0), 1-3. https://doi.org/10.1080/02607476.2020.1755205

Morgan, H. (2020). Best practices for implementing remote learning during a pandemic. The Clearing House: A Journal of Educational Strategies, Issues and Ideas, 93(3), 135-141. https://doi.org/10.1080/00098655.2020.1751480

Mubarak, M. R., Ahmadi, A., \& Audina, N. A. (2020). Kombinasi strategi bernyanyi dan bermain: Upaya dalam menumbuhkan motivasi mahasiswa tadris biologi (TBG) dalam pembelajaran bahasa Arab. ALSUNIYAT: Jurnal Penelitian Bahasa, Sastra, dan Budaya Arab, 3(1), 15-31. https://doi.org/10.17509/alsuniyat.v3i1.23996

Mubarak, M. R., Wahdah, N., Ilmiani, A. M., \& Hamidah, H. (2020a). Penggunaan vlog dalam pembelajaran mahārah kalām. Al Mi'yar: Jurnal Ilmiah Pembelajaran Bahasa Arab dan Kebahasaaraban, 3(1), 109-126. https://doi.org/10.35931/am.v3i1.209

Mubarak, M. R., Wahdah, N., Ilmiani, A. M., \& Hamidah, H. (2020b). Zoom cloud meeting: Media alternatif dalam pembelajaran mahārah kalam di tengah wabah virus Corona (Covid19). Arabiyatuna: Jurnal Bahasa Arab, 4(2), 211-226. https://doi.org/10.29240/jba.v4i2.1445

Murphy, M. P. A. (2020). COVID-19 and emergency eLearning: Consequences of the securitization of higher education for post-pandemic pedagogy. Contemporary Security Policy, 41(3), 492-505. https://doi.org/10.1080/13523260.2020.1761749

Nuha, U. (2016). Ragam metodologi \& media pembelajaran bahasa Arab. Diva Press.

Nurtresnaningsih, I. (2018). Problematika siswa dalam pembelajaran bahasa Arab serta upaya dalam menanggulanginya. ALSUNIYAT: Jurnal Penelitian Bahasa, Sastra, dan Budaya Arab, 1(1), 17-29. https://doi.org/10.17509/alsuniyat.v1i1.24196 
Raaper, R., \& Brown, C. (2020). The Covid-19 pandemic and the dissolution of the university campus: Implications for student support practice. Journal of Professional Capital and Community, 5(3/4), 343-349. https://doi.org/10.1108/JPCC-06-2020-0032

Rachman, M. K., Hanna, H., Badara, A., Atikah, D., \& Nurfaidah, S. (2020). EFL Students' reflection on the use of Madlipz in listening class. Proceeding of USN Kolaka-ADRI International Conference on Sustainable Coastal-Community Development, 1(0), 30-34. https://doi.org/10.31327/icusn-adri.v1i0.1057

Rozak, A., \& Albantani, A. M. (2018). Desain perkuliahan bahasa Arab melalui Google Classroom. Arabiyat: Jurnal Pendidikan Bahasa Arab dan Kebahasaaraban, 5(1), 83-102. https://doi.org/10.15408/a.v5i1.7481

Sa`diyah, H. (2019). Upaya menumbuhkan self-confidence berbicara bahasa Arab mahasiswa melalui grup Whatsapp. Al Mi'yar: Jurnal Ilmiah Pembelajaran Bahasa Arab dan Kebahasaaraban, 2(2), 149-164. https://doi.org/10.35931/am.v2i2.119

Simamora, R. M. (2020). The Challenges of online learning during the COVID-19 pandemic: An essay analysis of performing arts education students. Studies in Learning and Teaching, 1(2), 86-103. https://doi.org/10.46627/silet.v1i2.38

Supiani, Rafidiyah, D., Yansyah, \& Nadia, H. (2020). The emotional experiences of Indonesian $\mathrm{PhD}$ students studying in Australia during the COVID-19 pandemic. Journal of International Students, 10(S3), 108-125.

Susanto, G., Suparmi, \& Rahayu, E. Y. (2020). The emotional geography of international students in online bahasa Indonesia learning during the COVID-19 pandemic. Journal of International Students, 10(S3), 161-179. https://doi.org/10.32674/jis.v10iS3.3205

Taloko, J. L., Putra, M. S., \& Hartanto, Y. (2020). Emotional geographies experienced by an Indonesian doctoral student pursuing her PhD in New Zealand during the COVID-19 pandemic. Journal of International Students, 10(S3), 126-141.

Taylor, S. J., Bogdan, R., \& DeVault, M. L. (2015). Introduction to qualitative research methods: $A$ guidebook and resource.

Xue, E., Li, J., Li, T., \& Shang, W. (2020). China's education response to COVID-19: A perspective of policy analysis. Educational Philosophy and Theory, o(0), 1-13. https://doi.org/10.1080/00131857.2020.1793653

Zhu, X., \& Liu, J. (2020). Education in and after Covid-19: Immediate responses and long-term visions. Postdigital Science and Education, 1-5. https://doi.org/10.1007/s42438-02000126-3 